Jurnal Penelitian dan Pengabdian Kepada Masyarakat Bidang ilmu Pendidikan

\title{
Pengaruh Penggunaan Google Classroom terhadap Motivasi Belajar Mahasiswa STKIP Yapis Dompu
}

\author{
Supriyaddin \\ Program studi Pendidikan Teknologi Informasi, STKIP Yapis Dompu \\ E-mail corresponding: supriyaddin2000@gmail.com
}

Article History: Received: 2021-07-22 || Revised: 2021-07-28 || Published: 2021-08-31

Sejarah Artikel : Diterima: 2021-07-22 || Direvisi: 2021-07-28 || Dipublikasi: 2021-08-31

\begin{abstract}
Research entitled the effect of using Google Classroom on student learning motivation at STKIP Yapis Dompu with the aim of knowing the effect of using Google Classroom on learning motivation at STKIP Yapis Dompu. The approach used in this research is quantitative. The population and sample are STKIP Yapis Dompu Information Technology Education Students Class of 2018 in the E-Learning Course with a total of 24 people. Sampling using saturated sampling technique. The correlation value of Google Classroom is 0.095 , it can be concluded that the use of Google Classroom is positively related to Learning Motivation but with a very weak relationship level because it is at the correlation level of 0.00-0.199. Based on the proposed hypothesis, there is an effect of using Google Classroom on the learning motivation of STKIP Yapis Dompu students.
\end{abstract}

Keywords: Google, Classroom, Motivation.

\begin{abstract}
Abstrak
Penelitian dengan judul pengaruh penggunaan Google Classroom terhadap motivasi belajar mahasiswa di STKIP Yapis Dompu dengan tujuan untuk mengetahui pengaruh penggunaan Google Classroom terhadap motivasi belajar STKIP Yapis Dompu, pendekatan yang digunakan dalam penelitian ini adalah kuantitatif, populasi dan sampel yakni Mahasiswa Pendidikan Teknologi Informasi STKIP Yapis Dompu Angkatan 2018 pada Mata Kuliah E-Learning dengan jumlah 24 orang, pengambilan sampel dengan menggunakan teknik sampling jenuh. Nilai korelasi Google Classroom adalah 0,095, maka dapat disimpulkan bahwa penggunaan Google Classroom berhubungan secara positif terhadap motivasi belajar namun dengan tingkat hubungan sangat lemah karena berada pada tingkat korelasi 0,00-0,199. Berdasarkan hipotesis yang diajukan, maka terdapat pengaruh penggunaan Google Classroom terhadap motivasi belajar Mahasiswa STKIP Yapis Dompu.
\end{abstract}

Kata kunci: Google, Classroom, Motivasi.

\section{PENDAHULUAN}

Di era sekarang, seiring berkembangnya teknologi tentunya memberikan kesempatan bagi dosen memupuk keterampilan dalam menggunakan media dan bahan ajar dengan tujuan dapat menumbuhkan motivasi mahasiswa untuk lebih semangat dalam melaksanakan kegiatan belajar. Sebagaimana yang tercantum dalam Peraturan Menteri Pendidikan dan Kebudayaan Republik Indonesia nomor 109 tahun 2013, tentang penyelenggaraan pendidikan jarak jauh pada perguruan tinggi untuk memberikan layanan Pendidikan tinggi kepada kelompok masyarakat yang tidak dapat mengikuti pendidikan secara tatap muka dan memperluas akses serta mempermudah layanan pendidikan tinggi dalam pendidikan dan pembelajaran, Tujuannya untuk mendorong penyelenggara pembelajaran yang efektif dan efisien. Dengan demikian, pembelajaran dengan integritas teknologi informasi merupakan upaya untuk meningkatkan mutu dan kualiatas kegiatan belajar mengajar. Dalam rangka mensinergikan proses modernisasi dan kualiatas pembelajaran, maka perlu adanya perubahan paradigma yang dilakukan oleh dosen dalam melaksanakan proses pembelajaran di kampus STKIP Yapis Dompu.

Kini Dosen juga harus mampu menguasai dalam mengoperasikan teknologi informasi serta mengaplikasikannya dalam pembelajaran diruangan maupun luar ruangan. Hal ini bertujuan untuk meningkatakan kualiatas pembelajaran dan kualitas lulusan (output) yang mampu bersaing di era moderen ini. Pembelajaran di era moderen, lebih diarahkan pada aktivitas modernisasi dengan bantuan teknologi canggih dengan harapan dapat membantu mahasiswa dalam mencerna materi 
pelajaran secara interaktif, produktif, efektif, inspiratif, konstruktif dan menyenangkan, Selain itu, mahasiswa juga diharapkan memiliki life skill dari aplikasi teknologi tersebut. Adapun aplikasi dari teknologi informasi dan komunikasi yang potensial untuk dimanfaatkan sebagai media pembelajaran ialah internet, sudah cukup banyak kampus- kampus yang memilki komputer yang terkoneksi (link) internet. Google for education merupakan produk yang dibuat untuk memberikan kesempatan kepada para Dosen untuk mengeksplorisasi gagasan keilmuan yang dimilikinya kepada mahasiswa.

Berdasarkan hasil wawancara pada tanggal 15 April 2021 dengan Ketua Program Teknologi Informasi, dan beberapa Dosen khususnya Dosen Mata Kuliah E-Learning STKIP Yapis Dompu, saat awal diumumkannya kuliah di rumah dan pembelajaran beralih ke pembelajaran dalam jaringan (daring), hari pertama langsung Wakil Ketua Bidang Akademik menentukan bahwa salah satu aplikasi Google Classroom untuk dijadikan solusi dalam pembelajaran daring di tengah Pandemi Covid-19. Berdasarkan uraian diatas maka peneliti tertarik untuk melakukan penelitian dengan judul "Pengaruh penggunaan Google Clasroom terhadap motivasi belajar di STKIP Yapis Dompu".

\section{METODE PENELITIAN}

Pendekatan yang digunakan dalam penelitian ini adalah kuantitatif. Menurut Sugiyono (2016) metode penelitian kuantitatif adalah metode yang berlandaskan pada filsafat positivisme yang digunakan pada populasi atau sampel tertentu, filsafat positivisme memandang fenomena/gejala/realitas itu dapat diklasifikasikan, teramati, konkrit, terukur, dan hubungan gejala sebab akibat, Peneliti selanjutnya menyusun teknik analisis data. Teknik analisis data adalah suatu cara untuk mengolah sebuah data menjadi informasi sehingga karakteristik data tersebut menjadi mudah untuk dipahami, untuk memperoleh data yang tepat, relevan dan sesuai dengan kebutuhan penelitian tersebut, salah satu teknik pengumpulan data yang digunakan adalah kuesioner atau angket. Alasan peneliti mengumpulkan data menggunakan kuesioner atau angket karena kuesioner merupakan teknik pengumpulan data yang efisien bila peneliti tahu dengan pasti variabel yang akan diukur dan apa yang bisa diharapkan dari responden.

Peneliti menggunakan skala Likert untuk mengukur respon, pendapat dan persepsi seseorang atau sekelompok orang tentang fenomena sosial. Jawaban setiap item soal yang menggunakan skala Likert memiliki pilihan dengan SS $($ Sangat Setuju $)=5 . S($ Setuju $)=4$. $($ Ragu-ragu $)=3$. TS $($ Tidak Setuju) $=2$. STS (Sangat Tidak Setuju) $=1$, setelah instrumen disusun, maka langkah selanjutnya adalah menguji validitas instrument. Dengan menggunakan instrument yang valid dalam pengumpulan data diharapkan hasil penelitian menjadi valid. adapun teknik analisis data sebagai berikut:

a) Uji Coba Instrumen

(1) Uji Validitas

Kuesioner dikatakan valid apabila mampu mengungkapkan nilai variabel yang diteliti. Uji validitas dilakukan dengan membandingkan antara nilai $r$ hitung dengan nilai $r$ tabel dengan nilai signifikansi $(\alpha)=0,05$. Jika $r$ hitung $>$ dari $r$ tabel dan bernilai $r$ positif, maka butir pernyataan valid. Sebaliknya, jika $r$ hitung $<r$ tabel maka pernyataan dapat dikatakan tidak valid. Uji validitas dilakukan dengan menggunakan bantuan aplikasi SPSS versi 21.00 .

(2) Uji Reliabilitas

Jika nilai Cronbach Alpha lebih besar daripada tingkat signifikansi yang digunakan, maka pertanyaan dianggap reliable.

Tabel 1. Interpretasi nilai $r$

\begin{tabular}{|c|c|}
\hline Besarnya Nilai $\mathbf{r}$ & Interpretasi \\
\hline Antara $0,00-0,20$ & Sangat Rendah \\
\hline Antara $0,20-0,40$ & Rendah \\
\hline Antara $0,40-0,60$ & Cukup \\
\hline Antara $0,60-0,80$ & Kuat \\
\hline Antara $0,80-1,00$ & Sangat Kuat \\
\hline
\end{tabular}


b) Uji Regresi Linear Sederhana

Analisis regresi linier sederhana adalah untuk menguji pengaruh masing-masing variabel bebas/independen $(\mathrm{X})$ terhadap variabel terikat/dependen (Y). Analisis regresi linear sederhana ini digunakan untuk menguji pengaruh penggunaan aplikasi Google Classroom (X) terhadap motivasi belajar (Y). Untuk melakukan pengujian, maka peneliti menggunakan program SPSS versi 2, berikut persamaan dari regresi linear sederhana yang digunakan dalam penelitian ini:

$$
Y^{\prime}=a+b X
$$

Keterangan:

$$
\begin{aligned}
& Y^{\prime}=\text { Variabel Motivasi Belajar } \\
& X=\text { Variabel Google Classroom } \\
& a=\text { Konstanta } \\
& b=\text { Koefisien regresi }
\end{aligned}
$$

c) Pengujian Hipotesis

Pengujian hipotesis dalam penelitian ini menggunakan analisis dengan Uji Korelasi Product Moment Pearson, menggunakan program SPSS. Sugiyono (2013) analisis korelasi parsial digunakan untuk mengetahui seberapa besar kekuatan hubungan antara korelasi kedua variabel dimana variabel lainnya yang dianggap berpengaruh dikendalikan atau dibuat sebagai variabel kontrol atau tetap. Teknik statistik yang digunakan adalah Pearson Correlation Product Moment dengan bantuan SPSS versi 21.00.

Tabel 2. Interpretasi Koefisien Korelasi

\begin{tabular}{|c|c|}
\hline Interval Koefisien & Tingkat Hubungan \\
\hline $0,00-0,199$ & Sangat Lemah \\
\hline $0,20-0,399$ & Lemah \\
\hline $0,40-0,599$ & Sedang \\
\hline $0,60-0,799$ & Kuat \\
\hline $0,80-1,00$ & Sangat Kuat \\
\hline & Sumber: Sugiyono (2013) \\
\hline
\end{tabular}

\section{HASIL DAN PEMBAHASAN}

\section{A. Uji Validitas}

1) Uji Validitas instrumen Penggunaan Google Classroom

Uji validitas dalam penelitian ini dihitung berdasarkan variabel dari penggunaan Google Classroom. Data diambil dari 24 responden dan selanjutnya diolah dengan SPSS Versi 21.00. Perhitungan uji validitas instrumen berdasarkan perbandingan antara rhitung dan rtabel dimana rtabel dengan tingkat signifikansi $(\alpha)$ sebesar 0,05 diperoleh hasil sebesar 0,404.

\begin{tabular}{|c|c|c|c|}
\hline Item X Ke & rHitung & rTabel & Keterangan \\
\hline 1 & 0,694 & \multirow{11}{*}{0,404} & Valid \\
\hline 2 & 0,689 & & Valid \\
\hline 3 & 0,702 & & Valid \\
\hline 4 & 0,692 & & Valid \\
\hline 5 & 0,688 & & Valid \\
\hline 6 & 0,708 & & Valid \\
\hline 7 & 0,681 & & Valid \\
\hline 8 & 0,699 & & Valid \\
\hline 9 & 0,697 & & Valid \\
\hline 10 & 0,703 & & Valid \\
\hline 11 & 0,701 & & Valid \\
\hline
\end{tabular}
Apabila rhitung lebih besar dari rtabel, maka pernyataan dianggap valid, sedangkan apabila rhitung lebih kecil dari rtabel, maka pernyataan dianggap tidak valid. Berikut adalah hasil dari uji validitas yang dilakukan:

Tabel 3. Hasil Uji Validitas Instrumen Penggunaan Google Classroom (Variabel X) 
2) Uji Validitas Variabel Motivasi Belajar

Uji validitas dalam penelitian ini dihitung berdasarkan variabel dari motivasi belajar. Data diambil dari 24 responden dan selanjutnya diolah dengan SPSS Versi 21.00. Perhitungan uji validitas instrumen berdasarkan perbandingan antara rhitung dan rtabel dimana rtabel dengan tingkat signifikansi $(\alpha)$ sebesar 0,05 diperoleh hasil sebesar 0,404. Apabila rhitung lebih besar dari rtabel, maka peryataan dianggap valid, sedangkan apabila rhitung lebih kecil dari rtabel, maka pernyataan dianggap tidak valid. Berikut adalah hasil dari uji validitas yang dilakukan:

Tabel 4. Hasil Uji Validitas Instrumen Motivasi Belajar (Variabel Y)

\begin{tabular}{|c|c|c|c|}
\hline Item X Ke & rHitung & rTabel & Keterangan \\
\hline 1 & 0,661 & \multirow{16}{*}{0,404} & Valid \\
\hline 2 & 0,678 & & Valid \\
\hline 3 & 0,670 & & Valid \\
\hline 4 & 0,658 & & Valid \\
\hline 5 & 0,652 & & Valid \\
\hline 6 & 0,671 & & Valid \\
\hline 7 & 0,652 & & Valid \\
\hline 8 & 0,661 & & Valid \\
\hline 9 & 0,668 & & Valid \\
\hline 10 & 0,673 & & Valid \\
\hline 11 & 0,668 & & Valid \\
\hline 12 & 0,684 & & Valid \\
\hline 13 & 0674 & & Valid \\
\hline 14 & 0,681 & & Valid \\
\hline 15 & 0,680 & & Valid \\
\hline 16 & 0,660 & & Valid \\
\hline
\end{tabular}

\section{B. Uji Reliabilitas}

1) Uji Reliabilitas Instrumen Penggunaan Google Classroom

Kriterianya: instrumen memiliki tingkat reliabilitas yang tinggi jika nilai koefisien yang diperoleh > 0,60 (Ghozali,2007).

Tabel 5. Hasil Uji Reliabilitas Instrumen Penggunaan Google Classroom

\begin{tabular}{|r|r|r|}
\hline Cronbach's & Cronbach's Alpha Based on & N of \\
\hline .713 & .773 & 12 \\
\hline
\end{tabular}

Berdasarkan data tabel $5 \mathrm{di}$ atas dapat disimpulkan nilai perhitungan reliabilitas berada pada nilai 0,713 dari 11 item pernyataan, yang artinya adalah nilai tersebut reliabel dan dalam kategori tinggi atau kuat.

2) Uji Reliabilitas Instrumen Penggunaan Motivasi Belajar

Kriterianya: instrumen memiliki tingkat reliabilitas yang tinggi jika nilai koefisien yang diperoleh > 0,60 (Ghozali,2007).

Tabel 6. Hasil Uji Reliabilitas Instrumen Penggunaan Motivasi Belajar

\begin{tabular}{|c|c|c|}
\hline Cronbach's Alpha & $\begin{array}{c}\text { Cronbach's Alpha Based on } \\
\text { Standardized Items }\end{array}$ & $\begin{array}{l}\mathrm{N} \text { of } \\
\text { Items }\end{array}$ \\
\hline .681 & .701 & 17 \\
\hline
\end{tabular}

Berdasarkan data tabel 6 di atas dapat disimpulkan nilai perhitungan reliabilitas berada pada nilai 0,681 dari 16 item pernyataan, yang artinya adalah nilai tersebut reliabel dan dalam kategori tinggi atau kuat, hasil uji reliabilitas selengkapnya bisa dilihat pada lampiran. 


\section{Uji Regresi Linear Sederhana}

Analisis regresi linear sederhana ini digunakan untuk menguji pengaruh penggunaan Google Classroom (X) terhadap Motivasi belajar (Y). Adapun dasar pengambilan keputusannya adalah sebagai berikut:

$$
\begin{aligned}
& 0,00-0,25=\text { Sangat Lemah } \\
& 0,26-0,50=\text { Hubungan sedang } \\
& 0,51-0,75=\text { Hubungan kuat } \\
& 0,76-1,00=\text { Hubungan sangat kuat } / \text { Sempurna }
\end{aligned}
$$

Tabel 7. Hasil Uji Regresi Linear Sederhana (Tabel Model Summary)

\begin{tabular}{|c|c|c|}
\hline Model & R & R Square \\
\hline 1 & 0,095 & 0,009 \\
\hline \multicolumn{2}{|c|}{ Sumber: Data Primer Penelitian (2021) } \\
\hline
\end{tabular}

Berdasarkan tabel 7 di atas, hasil uji regresi linear sederhana diketahui bahwa nilai R sebesar 0,095 atau dalam kata lain terdapat korelasi (hubungan) antar variabel namun sangat lemah karena nilainya kurang dari 0,25. Adapun $R$ Square pada uji regersi linear sederhana ini adalah 0,009.

Tabel 8. Hasil Uji Regresi Linear Sederhana (Tabel Koefisien)

\begin{tabular}{|c|c|c|}
\hline Model & Constant & R \\
\hline 1 & 64,732 & 0,097 \\
\hline
\end{tabular}

Rumus regresi linear sederhana:

Nilai Constant (a) $=64,732$ Nilai

Nilai Constant (b) $=0,097$

$\mathrm{Y}=\mathrm{a}+\mathrm{bX}$

Motivasi Belajar $=64,732+0,097$ (Google Classroom)

Dari nilai $b=0,097$ berarti bahwa variabel Motivasi Belajar berpengaruh sebesar 0,097 dengan kata lain penggunaan Google Classroom berpengaruh sebesar 9,7\%.

\section{Uji Hipotesis}

Pengujian hipotesis ini dengan menggunakan uji Korelasi Product Moment Pearson. Uji korelasi Product Moment Pearson bertujuan untuk mengetahui tingkat keeratan hubungan antar variabel yang dinyatakan dengan koefisien korelasi (r).

Tabel 9. Hasil Uji Korelasi Product Moment Pearson

\begin{tabular}{|c|c|c:c|}
\hline Model & Variabel X & Variabel Y & Korelasi \\
\hline 1 & Google Classroom & Motivasi Belajar & 0,095 \\
\hline
\end{tabular}

Berdasarkan tabel 9 di atas, dapat dilihat bahwa nilai korelasi Google Classroom adalah 0,095, maka dapat disimpulkan bahwa penggunaan Google Classroom berhubungan secara positif terhadap Motivasi Belajar namun dengan tingkat hubungan sangat lemah karena berada pada tingkat korelasi 0,00 0,199 .

\section{SIMPULAN DAN SARAN}

\section{A. Simpulan}

Berdasarkan hasil yang telah diperoleh dari analisis, maka dapat disimpulkan bahwa penggunaan Google Classroom memiliki pengaruh yang positif terhadap motivasi belajar mahasiswa Pendidikan Teknologi Informasi angkatan 2018 STKIP Yapis Dompu. Namun, walaupun penggunaan Google Classroom memiliki pengaruh tetapi, pengaruhnya terhadap motivasi belajar adalah sangat rendah, hal ini dikarenakan tingat signifikansi Google Classroom adalah 0,095 yang berarti berada pada tingkat hubungan 0,00-0,199 (Sangat lemah). 


\section{B. Saran}

Berdasarkan hasil penelitian yang telah dilakukan, salah satu saran yang dapat dikemukakan oleh peneliti yaitu diharapkan penelitian selanjutnya tidak halnya respon mahasiswa namun juga respon dosen terhadap penggunaan Google Classroom dalam melaksanakan proses pembelajaran.

\section{DAFTAR RUJUKAN}

Ghozali, Imam. (2007). Aplikasi Analisis Multivariate Dengan Program SPSS. Semarang : Universitas Diponogoro.

Kemendikbud. (2013). Permendikbud Nomor 109 Tahun 2013. Tentang Penyelenggaraan Pendidikan Jarak Jauh Pada Pendidikan Tinggi. Jakarta: Kemendikbud.

Prasetyo. Bambang. (2006). Metode Penelitian Kuantitatif : Teori dan Aplikasi. Jakarta : Raja Grafindo Persada.

Sugiyono. (2013). Metode Penelitian Pendidikan Pendekatan Kuantitatif, Kualitatif, dan R\&D. Bandung : Alfabeta.

Sugiyono. (2016). Metode Penelitian Kuantitatif, Kualitatif dan R\&D. Bandung : Alfabeta.

Enung Nurhasanah. (2021). Pengembangan Multimedia Pembelajaran Sejarah Perkembangan Islam Berbasis Macromedia Flash untuk Meningkatkan Hasil Belajar Mahasiswa. Ainara Journal (Jurnal Penelitian Dan PKM Bidang Ilmu Pendidikan),2(3), 148-153. Retrieved from http://journal.ainarapress.org/index.php/ainj/article/view/69

Fakih, Mansour. 2006. Metode Kualitatif dan Kuantitatif, Yogyakarta: Graha Ilmu.

Fathirma'ruf. (2021). Pengembangan Game Edukasi Berbasis Flash Sebagai Sarana Belajar Siswa PAUD. Ainara Journal (Jurnal Penelitian Dan PKM Bidang Ilmu Pendidikan), 2(3), 143-147. Retrieved from http://journal.ainarapress.org/index.php/ainj/article/view/68

Friendrich Engels, 1844. Kritik Terhadap Hegelian Muda dan Trend Pemikiran Mereka. Pustaka Belajar. Gegne (dalam Pribadi, 2009:9) 